\title{
Oxidation Studies On 209 T1 and 213 T11 Alloys With Inhibition Corrosion By Using Mgo
}

\author{
Asst. Prof. Dr Kadhim. F. Al-Sultani \\ College of Materials Engineering- Babylon University- Iraq
}

\section{$\underline{\text { Abstract }}$}

Hot ash corrosion of high temperature combustion equipment from burning petroleum fuels containing $\mathrm{Na}, \mathrm{S}$ and $\mathrm{V}$, and recommendations for preventing or controlling fuel oil may result in severe damage to metal surfaces.

The use of $\mathrm{MgO}$ as a fuel additive to combact vanndic corrosion is widely accepted practice for boilers operating on residual or low grade fuels. $\mathrm{MgO}$ has the ability to form high melting stable vanadate but the presence of $\mathrm{Na}_{2} \mathrm{SO}_{4}$ can react with the magnesium and reduce its effectiveness. This paper aims to quantify the effectiveness of $\mathrm{MgO}$ as an inhibitor in the presence of increasing amounts of $\mathrm{Na}_{2} \mathrm{SO}_{4}$. Amethod of determining permissible levels of $\mathrm{Na}_{2} \mathrm{SO}_{4}$ to satisfy predict remind corrosion rates or additive efficiencies is described. Examples of the loss of additive efficiency with weight of $\mathrm{Na}_{2} \mathrm{SO}_{4}$ at temperature of 750 and $850^{\circ} \mathrm{C}$ are given for both $209 \mathrm{~T} 1$ and 213 T11 alloys.

Key-words : Furnace, $\mathrm{MgO}$, $\mathrm{Na}_{2} \mathrm{SO}_{4}, \mathrm{~V}_{2} \mathrm{O}_{5}$, balance 


\section{$\underline{\text { Introduction }}$}

\section{The relatively high}

content of vanadium, sodium and sulfur of heavy fuel oils leads to the formation of a mineral ash composed of sodium sulfate and vanadium pentoxide during ignition-Boilers burning low-grade or residual fuel oils suffer high temperature corrosion problems which can be directly attributed to the presence of fuel impurity combustion products $[1,2]$. The principal impurities associated with residual fuel oils are based on vanadium, sodium and sulphur and give rise to combustion products which may be present in their molten form on the outer surfaces of pipes boilers or in the atmosphere a round them, this indnced hot corrosion [3].

Hot corrosion occurs when metals are heated in the temperature range (700-800 c ) in the presence of deposits for med as a result reaction between sodium chloride and sulphur compounds in the gas phase surrounding the metals [4]. Hot corrosion is basically attack by fuel and /or ash compounds of $\mathrm{Na}, \mathrm{v}, \mathrm{s}$ and $\mathrm{C} /$ that are present in the coal or in fuel oil (heavy fuel oil ) used for combustion, in the mentioned application $[5,6]$

Various means were employed to prevent such corrosion, which is known as the hot ash corrosion. These include the use of highly resistant alloys [7] and the use of corrosion preventive additives to fuel oil. The first method needs high investment, whereas fuel additives receive much greater attention among engineers and scientists. Magnesium is the most important constituent of these additives [8].

Magnesium inhibits the formation of the low melting sodium vanadyl vanadate sulfate by forming magnesium vanadates melting at perform this jop, but it is an insoluble and rather non-miscible solid with the fuel oil. The miscibility requires extremely fine 
particles to ensure even dispersion and hence better reaction with fuel mineral constituents $\quad[8,10$ temperature higher than $1000^{\circ} \mathrm{C}$ [9]. Magnesium oxide is an excellent candidate to].

The corrosion of boilers pipes alloys can be markedly reduced by using $\mathrm{MgO}$ in such that a molecular ratio of 3 MgO: $\quad 1 \quad \mathrm{~V}_{2} \mathrm{O}_{5}$ is maintained in the deposit an the alloy surface. When the ratio $\mathrm{MgO}$ : $\mathrm{V}_{2} \mathrm{O}_{5}$ was less than $3: 1$ the reaction products contained $\mathrm{Mg}_{3} \mathrm{~V}_{2} \mathrm{O}_{8}$ and excess $\mathrm{V}_{2} \mathrm{O}_{5}$, whilst when the ratio exceeded 3:1, excess $\mathrm{MgO}$ was formed in the reaction products. However, the $\mathrm{MgO}-\mathrm{V}_{2} \mathrm{O}_{5}$ system is also affected by the presence of $\mathrm{Na}_{2} \mathrm{SO}_{4}$ from sulphur and sodium contamination in the fuel $[10,11]$.

The aim of the present work is to study the preparation of several magnesium containing additives and their application with synthetic mineral ash on steel pieces of the same type used in the pipes and structures of the Power Generation Stations.

Control of High Temperature Corrosion

There are three basic ways in which the environmental conditions can be modified to reduce high temperature problems and these are:

\section{Fuel Treatment.}

W ashed crude oils and residual-grade fuel oils are containing, vanadium, lead, nickel, sodium, potassium. In these applications the fuel has been purified through a centrifugal or electrostatic treatment plant to reduce water-soluble sodium and potassium contaminants to an acceptably low level (typically 0.5 or 1.0 ppm Na + K max.). [12]. 


\section{$\underline{\text { II. Fuel Additives }}$}

The remaining ash is resulted from in organic forms, principally vanadium, nickel, zinc and other trace metals. The corrosive effect of these elements can be neutralized by chemical additives. Fuel additives are oregano metallic compounds containing $\mathrm{Mg}, \mathrm{Al}, \mathrm{Si}, \mathrm{Cr}$ elements in the form of sulphonate or carboxylate. The concentration of active ingredient is $2-15 \% \mathrm{w} / \mathrm{w}$. Fuel treatment is the removal of at least the water soluble species by washing the fuel. [7,13].

The function of magnesium is to form magnesium vanadate compounds of melting point higher than $1100^{\circ} \mathrm{C}$ during combustion, instead of the low melting point,of sodium vanadate. The dose of magnesium is determined by the level of vanadium with respect to sodium in the oil. For example in case of $\mathrm{Na} / \mathrm{V}$ ratio is 0.1 and $\mathrm{Mg} / \mathrm{V}$ the ratio is $3 / 1[8,10]$.

\section{Protective Coating.}

Requirements for super alloys for boilers have been stated as follows:-

I. hot corrosion.

II. resist thermal fatigue cracking, and

III. resist particulate erosion.

All current coatings are based on the use of aluminum as the primary constituent. The processes used are:
A. Pack cementation.
B. Hot dipping.
C. Plasma spraying.
D. Cladding, and
E. Physical vapour deposition (PVD).[3].

\section{$\underline{\text { Experimental Methods }}$}

TO demonstrate the effects under investigation, two typical alloys were chosen. 209T1 and 213T11, tables $(1,2)$, were taken from South Baghdad Power Station (boilers pipes). Specimens were cut 
from this pipes into rectangular pieces $(5 * 15 * 25 \mathrm{~mm})$ (thickness * width * length). The surfaces of each sample were polished flat to $1000 \mu \mathrm{m}$ finish using SiC. Each specimen was then coated with $\mathrm{V}_{2} \mathrm{O}_{5}+\mathrm{Na}_{2} \mathrm{SO}_{4}$ or $\mathrm{V}_{2} \mathrm{O}_{5}+\mathrm{Na}_{2} \mathrm{SO}_{4}$ $+3 \mathrm{MgO}$, using the following method: a suspension of $\mathrm{V}_{2} \mathrm{O}_{5}+\mathrm{Na}_{2} \mathrm{SO}_{4}$ or $\mathrm{V}_{2} \mathrm{O}_{5}+\mathrm{Na}_{2} \mathrm{SO}_{4}+$ $3 \mathrm{MgO}$ in acetone was sprayed onto preheated $\quad\left(80-90^{\circ} \mathrm{C}\right) \quad$ alloy specimens. At this temperature the acetone evaporated, leaving the desired contaminant on the alloy surface.

Exposure tests were carried out in a tube furnace, samples, either coated or uncoated, were positioned in the hot zone of a furnace preheated to the required test temperature and exposed for 16 hours duration to the required test environment. The samples were exposed to air environment at a flow rate of $10 \mathrm{~cm}^{3} \mathrm{~min}^{-1}$ for the test duration.

Table (1) Chemical Analysis of (209T1) Alloy

\begin{tabular}{|c|c|c|c|c|c|c|c|c|}
\hline Component & $\mathrm{C}$ & $\mathrm{Mn}$ & $\mathrm{P}$ & $\mathrm{S}$ & $\mathrm{Si}$ & $\mathrm{Mo}$ & $\mathrm{Cr}$ & $\mathrm{Fe}$ \\
\hline Wt.\% & 0.15 & 0.5 & 0.025 & 0.035 & 0.25 & 0.35 & 0.080 & Rem. \\
\hline
\end{tabular}

Table (1) Chemical Analysis of (213T1) Alloy

\begin{tabular}{|c|c|c|c|c|c|c|c|c||}
\hline Component & $\mathrm{C}$ & $\mathrm{Mn}$ & $\mathrm{P}$ & $\mathrm{S}$ & $\mathrm{Si}$ & $\mathrm{Mo}$ & $\mathrm{Cr}$ & $\mathrm{Fe}$ \\
\hline Wt.\% & 0.1 & 0.4 & 0.025 & 0.025 & 0.7 & 0.55 & 1.5 & Rem. \\
\hline
\end{tabular}




\section{$\underline{\text { Results And Discussion }}$}

\section{$\underline{\text { A. Effect Of Contaminants And Inhibitor }}$}

The effects of various levels of $\mathrm{V}_{2} \mathrm{O}_{5}$ and $\mathrm{V}_{2} \mathrm{O}_{5}+3 \mathrm{MgO}$ upon the high temperature oxidation of $209 \mathrm{~T} 1$ and $213 \mathrm{~T} 11$ in the absence and presence of $\mathrm{Na}_{2} \mathrm{SO}_{4}$ contamination, are shown graphically in Figs. (1-6) as plots of corrosion loss $\left(\mathrm{g} \mathrm{cm}^{-2}\right)$ at (16h) vs. the amount of surface $\mathrm{V}_{2} \mathrm{O}_{5}$ $\left.(\mathrm{mg} \mathrm{cm})^{-2}\right)$ in various environments.

From the results in Figs. (1-6) the following points are evident:

(i) The presence of $\mathrm{V}_{2} \mathrm{O}_{5}$ on the surface of both $209 \mathrm{~T} 1$ and $213 \mathrm{~T} 11$ at $750^{\circ} \mathrm{C}$ and $850^{\circ} \mathrm{C}$ has resulted in enhanced high temperature oxidation which increases with both temperature and the amount of $\mathrm{V}_{2} \mathrm{O}_{5}$.

(ii) $209 \mathrm{~T} 1$ appears to be less resistance than 213 T11 towards
$\mathrm{V}_{2} \mathrm{O}_{5}$ and accelerated high temperature oxidation.

(iii) The addition of $\mathrm{MgO}$ to the $\mathrm{V}_{2} \mathrm{O}_{5}$ deposit (molecular ratio 3MgO: $1 \mathrm{~V}_{2} \mathrm{O}_{5}$ ) on both $209 \mathrm{~T} 1$ and $213 \mathrm{~T} 11$ at $750^{\circ} \mathrm{C}$ and $850^{\circ} \mathrm{C}$ has resulted in a marked reduction in measured corrosion over the (16h) test period. This behaviour is evident for all tested levels of $\mathrm{V}_{2} \mathrm{O}_{5}$ when a molecular ratio of $3 \mathrm{MgO}: 1 \mathrm{~V}_{2} \mathrm{O}_{5}$ is maintained on the alloy surface.

(iv) The presence of $\mathrm{Na}_{2} \mathrm{SO}_{4}$ contamination in the test atmosphere above the system [Alloy $+\mathrm{V}_{2} \mathrm{O}_{5}+3 \mathrm{MgO}$ (209 T1 and 213 T11)] results in a marked reduction in the effectiveness with which $\mathrm{MgO}$ inhibits $\mathrm{V}_{2} \mathrm{O}_{5}$ corrosion and 
hence an increase in the measured corrosion.

(v) The measured corrosion rises with increasing of $\mathrm{Na}_{2} \mathrm{SO}_{4}$ contamination. In fact, at the highest concentration $\mathrm{Na}_{2} \mathrm{SO}_{4}$ the corrosion is worse on the system Alloy+MgO $+\mathrm{V}_{2} \mathrm{O}_{5}+\mathrm{Na}_{2} \mathrm{SO}_{4}$ than if no $\mathrm{MgO}$ or $\mathrm{Na}_{2} \mathrm{SO}_{4}$ is present, i.e. Alloy $+\mathrm{V}_{2} \mathrm{O}_{5}+$ air,

From Figs. (1-6) it is evident that the additions of $\mathrm{MgO}$ to $\mathrm{a}_{2} \mathrm{O}_{5}$ deposit, using a molecular ratio of 3MgO: $1 \mathrm{~V}_{2} \mathrm{O}_{5}$, provides a viable method of reducing venadic corrosion. It can be seen from the above that corrosion control in low grade or residual fuel oils depends upon the formation of solid vanadium containing compounds and the formation of these compounds is modified by the presence of $\mathrm{Na}_{2} \mathrm{SO}_{4}$. The presence of $\mathrm{V}_{2} \mathrm{O}_{5}$ on both alloys which affords little protection to the underlying metal. The attack front is approximately uniform with scale are porous. The addition of $3 \mathrm{MgO}$ to the $\mathrm{V}_{2} \mathrm{O}_{5}$ gives slightly porous but coherent protective surface oxide which is thicker than that obtained in air with no $\mathrm{V}_{2} \mathrm{O}_{5}$ contamination. However, when $\mathrm{Na}_{2} \mathrm{SO}_{4}$ is also present (i.e. the system $\mathrm{V}_{2} \mathrm{O}_{5}+\mathrm{MgO}+\mathrm{Na}_{2} \mathrm{SO}_{4}$ + Air) the corrosive attack does give internal attack down grain boundaries and the outer scale is a typical vanadic corrosion scale. 


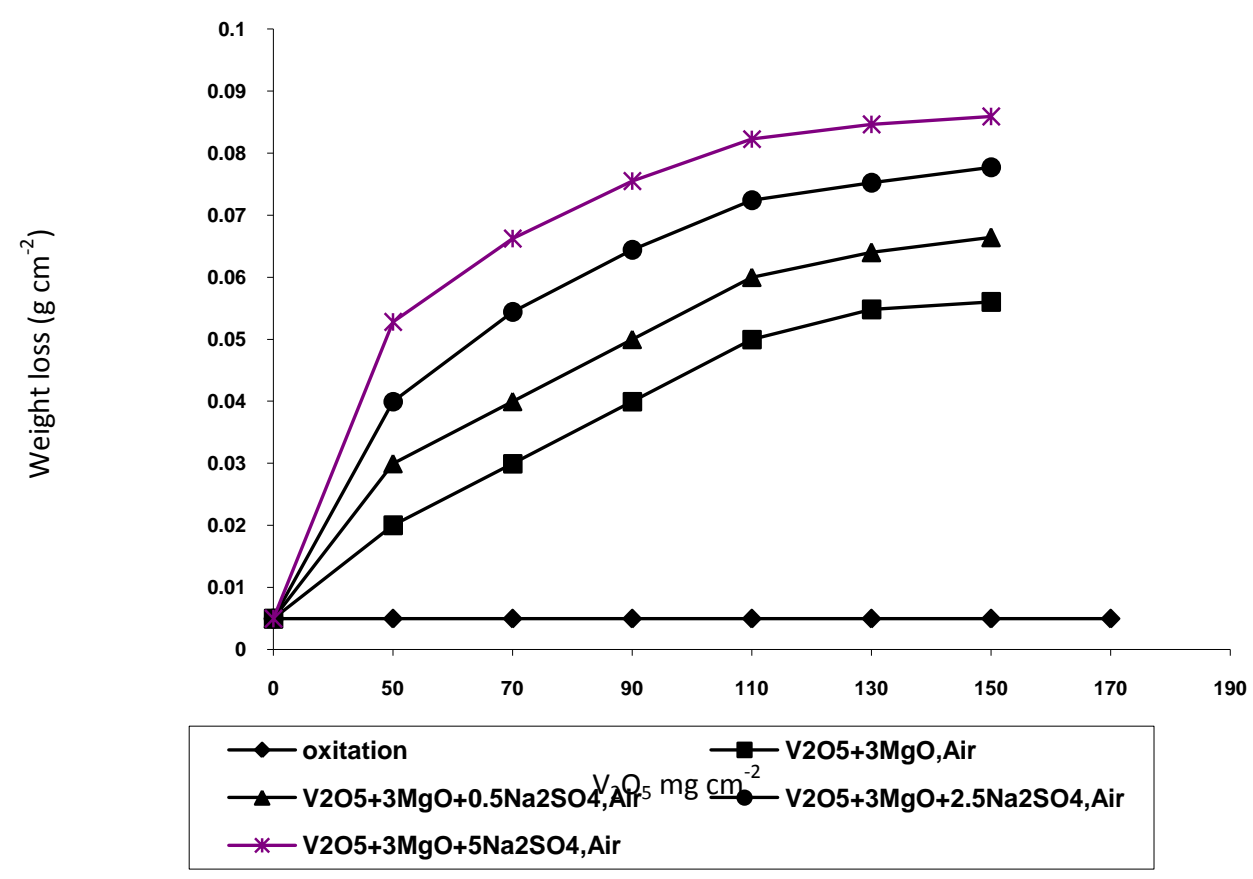

Fig.(1) Effect of contaminates and inhibitor on the high temperature corrosion of 209 $\mathrm{T} 1$ at $750{ }^{\circ} \mathrm{C}(16 \mathrm{~h})$.

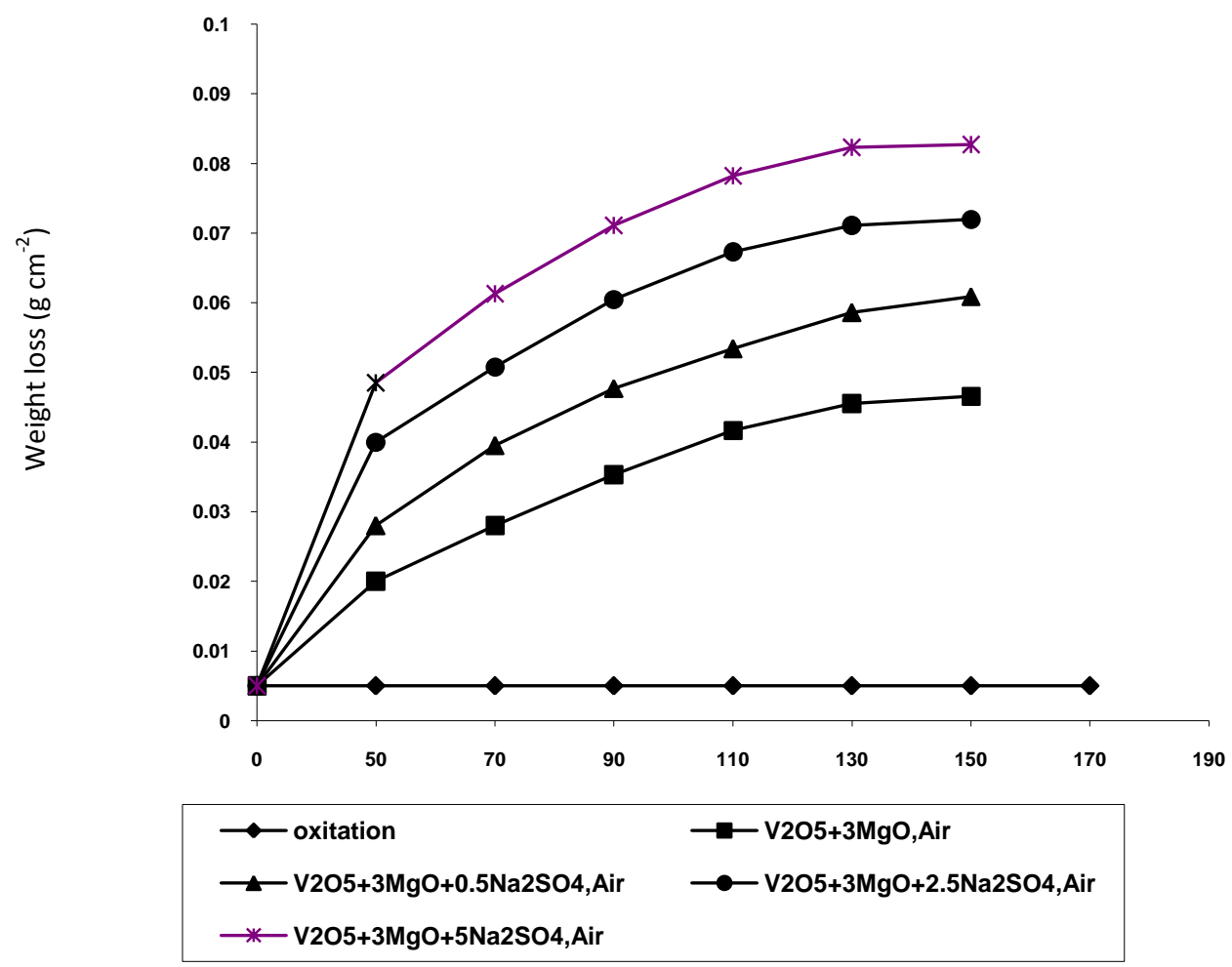

Fig.(2) Effect of contaminates and inhibitor on the high temperature corrosion of 209 $\mathrm{T} 1$ at $850{ }^{\circ} \mathrm{C}(16 h)$. 


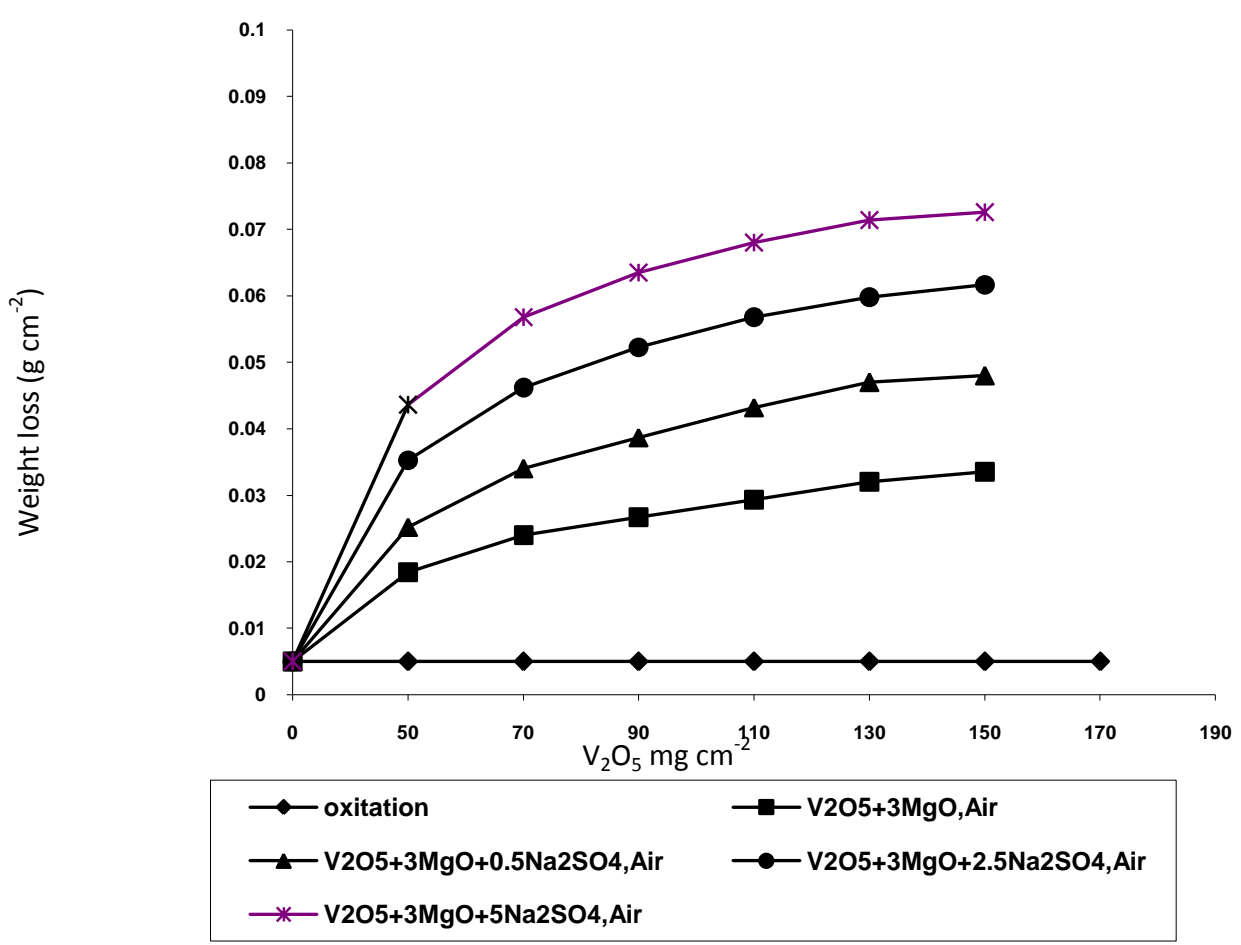

Fig.(3) Effect of contaminates and inhibitor on the high temperature corrosion of 213 T11 at $750{ }^{\circ} \mathrm{C}(16 h)$.

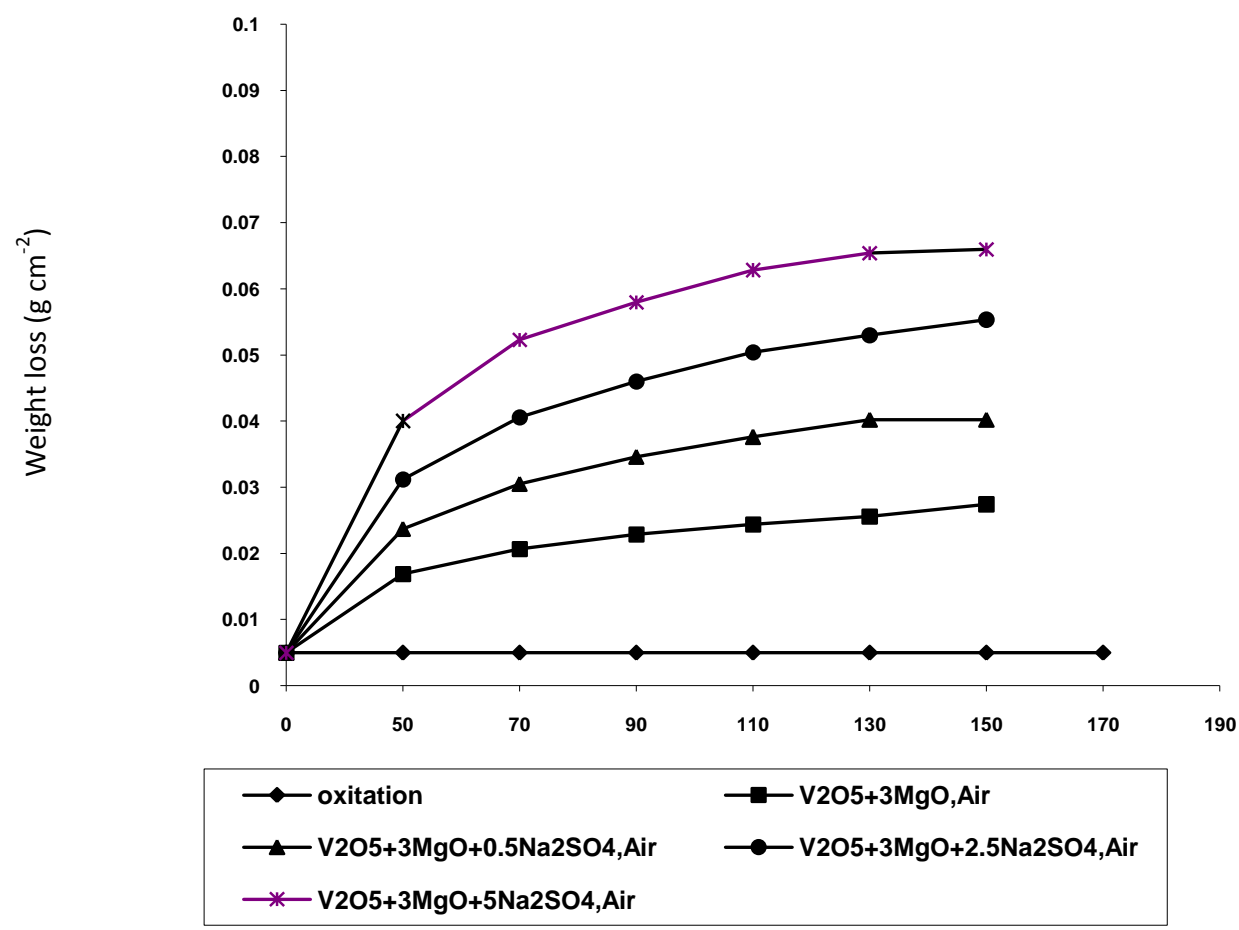

Fig.(4) Effect of contaminates and inhibitor on the high temperature corrosion of 213 T11 at $850{ }^{\circ} \mathrm{C}(16 h)$. 


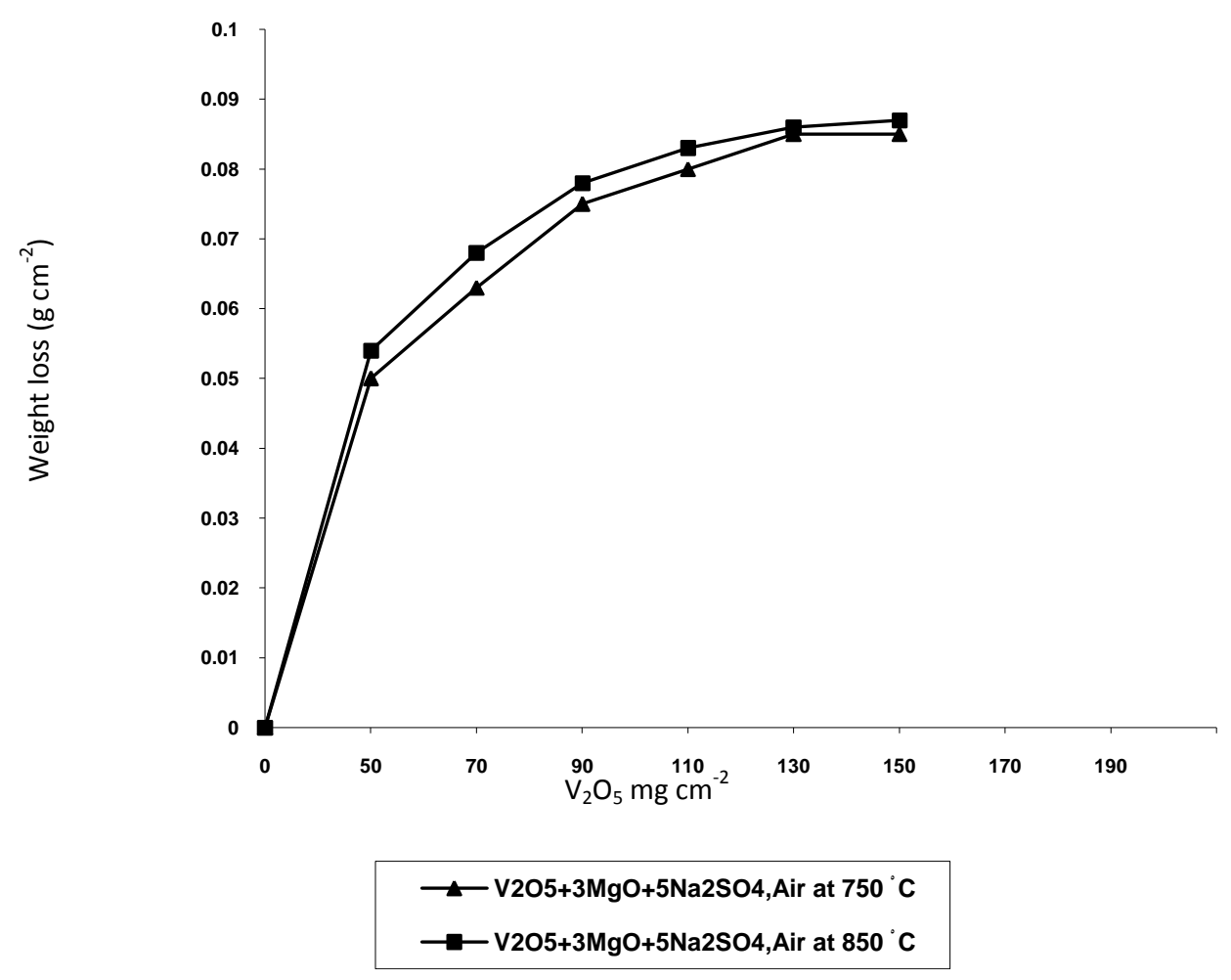

Fig.(5) Effect of contaminates and inhibitor on the high temperature corrosion of 209 $\mathrm{T} 1$ at 750 and $850{ }^{\circ} \mathrm{C}(16 h)$.

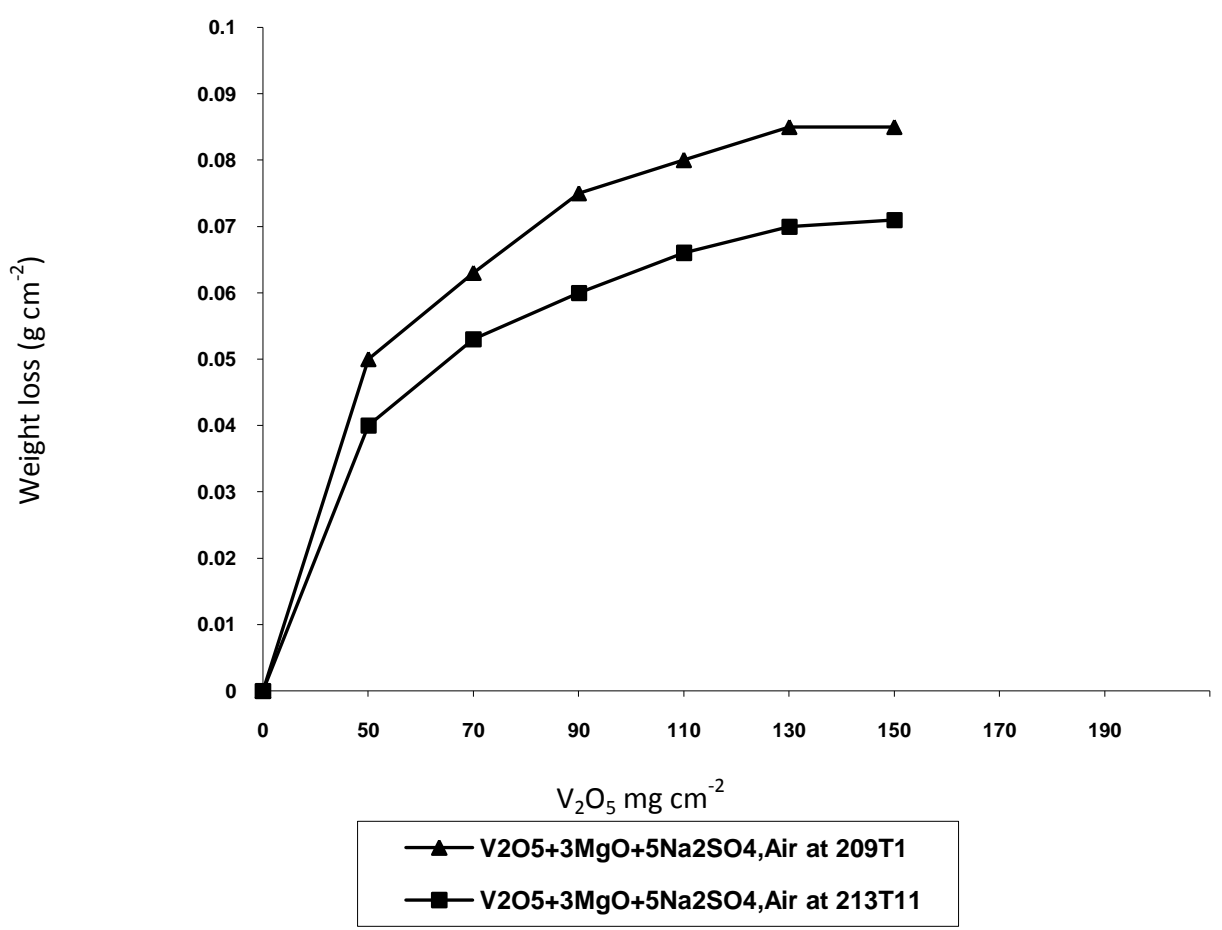

Fig.(6) Effect of contaminates and inhibitor on the high temperature corrosion of 209T1 and $213 \mathrm{~T} 11$ at $750^{\circ} \mathrm{C}(16 \mathrm{~h})$. 


\section{B. The Efficiency Inhibition}

$$
\text { TO express the effectiveness }
$$

with which $\mathrm{MgO}$ inhibits vanadic corrosion a term "inhibitor efficiency" may be evaluated as follows:

Inhibition Efficiency $\quad[\mathrm{I}]=$ $\frac{w_{1}-w_{2}}{w_{1}} \times 100$

Where: $w_{1}=$ weight loss in the system Alloy $+\mathrm{V}_{2} \mathrm{O}_{5}$, Air. $w_{2}=$ weight loss in the system Alloy $+\mathrm{V}_{2} \mathrm{O}_{5}+3 \mathrm{MgO}$, Air.

From Figs.(7-10) it is evident that for both 209T1 and 213T11 at 750 and $850^{\circ} \mathrm{C}$ the measured corrosion in $\mathrm{MgO}$ treated system is higher than that obtained for air oxidation and so the inhibitor is not $100 \%$ efficient.

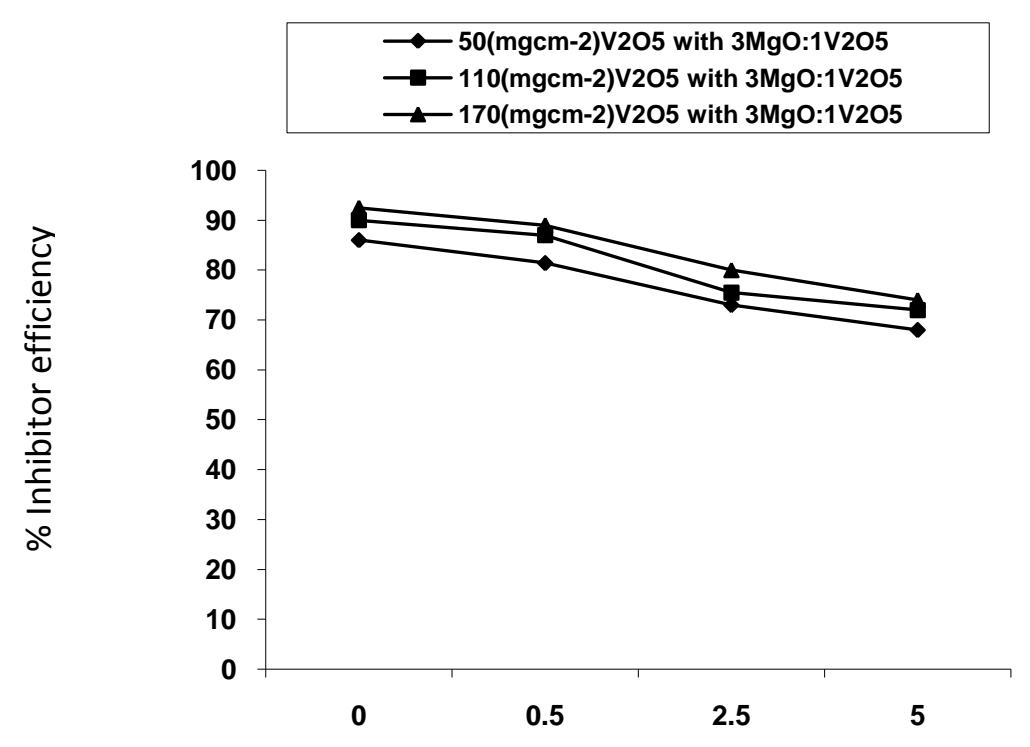

Fig. (7): Inhibitor efficiency $\mathrm{Vs} \mathrm{Na}_{2} \mathrm{SO}_{4}$ for the system $209 \mathrm{~T} 1\left(\mathrm{MgO}+\mathrm{V}_{2} \mathrm{O}_{5}+\mathrm{Na}_{2} \mathrm{SO}_{4}\right.$, Air $)$ at $750^{\circ} \mathrm{C}$ 


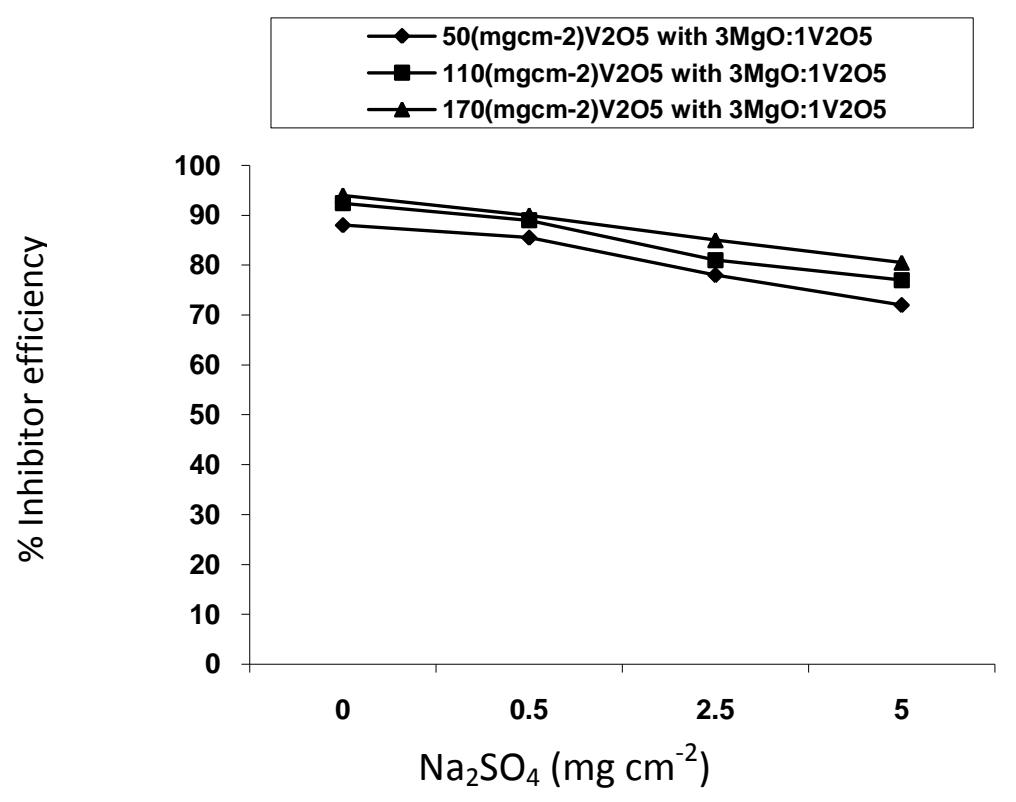

Fig.(8) Inhibitor efficiency $\mathrm{Vs} \mathrm{Na}_{2} \mathrm{SO}_{4}$ for the system $209 \mathrm{~T} 1\left(\mathrm{MgO}+\mathrm{V}_{2} \mathrm{O}_{5}+\mathrm{Na}_{2} \mathrm{SO}_{4}\right.$, Air $)$ at $850^{\circ} \mathrm{C}$

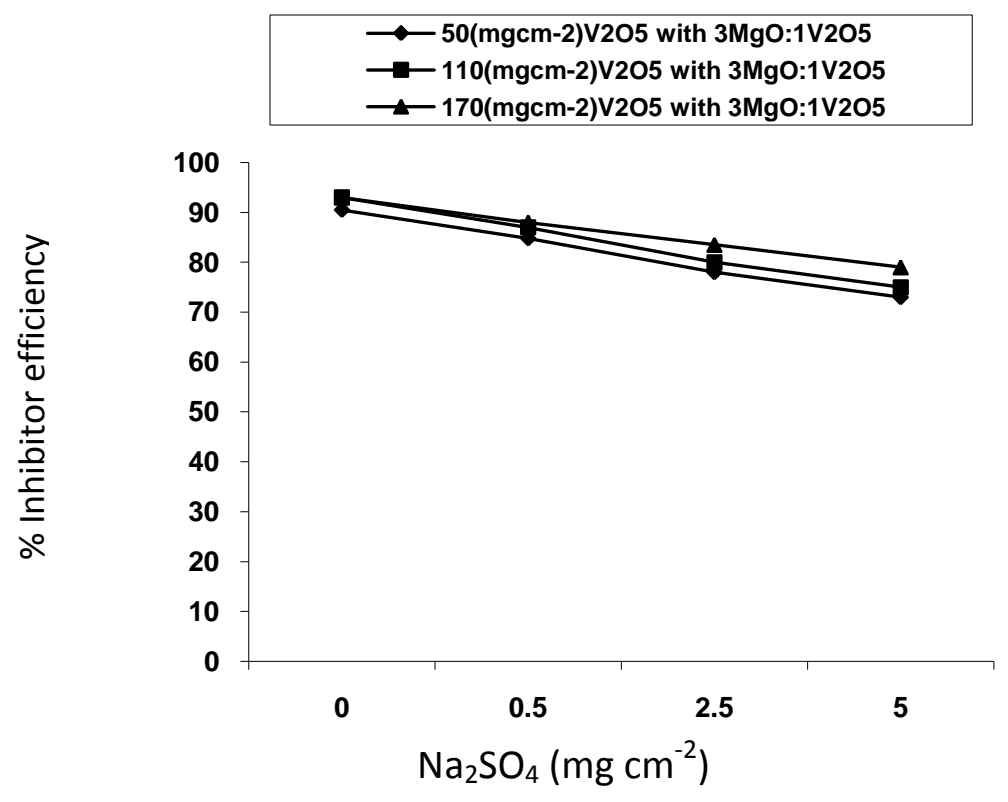

Fig.(9) Inhibitor efficiency $\mathrm{Vs} \mathrm{Na}_{2} \mathrm{SO}_{4}$ for the system $213 \mathrm{T11}\left(\mathrm{MgO}+\mathrm{V}_{2} \mathrm{O}_{5}+\mathrm{Na}_{2} \mathrm{SO}_{4}\right.$, Air) at $750^{\circ} \mathrm{C}$. 


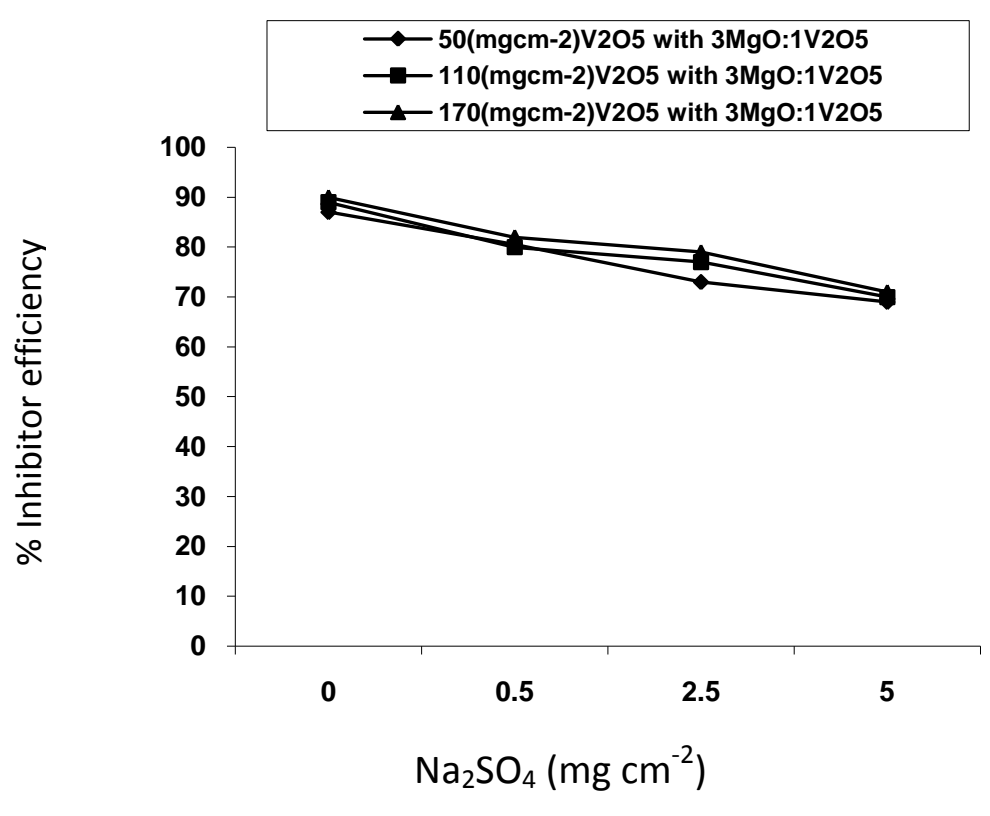

Fig. (10) Inhibitor efficiency $\mathrm{Vs}_{\text {. }} \mathrm{Na}_{2} \mathrm{SO}_{4}$ for the system $213 \mathrm{T11}\left(\mathrm{MgO}+\mathrm{V}_{2} \mathrm{O}_{5}+\mathrm{Na}_{2} \mathrm{SO}_{4}\right.$, Air $)$ at $850^{\circ} \mathrm{C}$

Figures (7-10) show plots of inhibitor efficiency (I), VS. $\mathrm{Na}_{2} \mathrm{SO}_{4}$ $\left(\mathrm{mg} \mathrm{cm} \mathrm{cm}^{-2}\right.$ ) for different amount of $\mathrm{V}_{2} \mathrm{O}_{5}+3 \mathrm{MgO}$. From the figures the following points are evident:

(i) For $209 \mathrm{~T} 1$ and $213 \mathrm{~T} 11$ at both test temperature the inhibitor efficiency falls with rising weight $\mathrm{Na}_{2} \mathrm{SO}_{4}$,

(ii) The beneficial effects of $\mathrm{MgO}$ aditions occurs at $\left(50-170 \mathrm{mg} \mathrm{cm}^{-}\right.$
2) $\mathrm{Na}_{2} \mathrm{SO}_{4}$ for $209 \mathrm{~T}_{1}$ and $213 \mathrm{~T}_{11}$ at both 750 and $850{ }^{\circ} \mathrm{C}$.

(iii) It would be expected that the specimen with the small a mount of $\mathrm{MgO}: \mathrm{V}_{2} \mathrm{O}_{5}$ deposits would be more susceptible to the influence of $\mathrm{Na}_{2} \mathrm{SO}_{4}$ present and this is demonstrated clearly by Figs.(710). This shows that deposition processes and rates will be of vital importance when trying to 
determine inhibitor efficiencies in oil fired boiler.

\section{Conclusions}

1. The vanadic corrosion of 209 $\mathrm{T}_{1}$ and $213 \mathrm{~T}_{11}$ has been shown to depend upon both the test temperature and amount of $\mathrm{V}_{2} \mathrm{O}_{5}$.

2. The effectiveness of $\mathrm{MgO}$ as an inhibitor of vanadic corrosion depends upon the amount of $\mathrm{Na}_{2} \mathrm{SO}_{4}$ present.

3. Plots I Vs. $\mathrm{Na}_{2} \mathrm{SO}_{4}\left(\mathrm{mg} \mathrm{cm}{ }^{-2}\right)$ can be used to find permissible levels of $\mathrm{Na}_{2} \mathrm{SO}_{4}$ to satisfy a preselected tolerable corrosion rate or inhibitor efficiency in a $\mathrm{V}_{2} \mathrm{O}_{5}+\mathrm{MgO}+\mathrm{Na}_{2} \mathrm{SO}_{4}+$ Air containment system. 


\section{$\underline{\text { References }}$}

1. O.M. Johnson, D. P. , (1975), Whittle and J. Stringer "Mechanisms of $\mathrm{Na}_{2} \mathrm{SO}_{4}$-Induced Accelerated Oxidation" Corrosion Science, Vol.15, PP. (721-739).

2. R.T. LeCren, (1992), "Advanced Combustion System for low-Grade Fules", Turbomachinery Technology Seminar, Catorpillar Solar Turbines.

3. S. Shawki, S. Hanna, (1985), "Corrosion Control in Gas Turbines" Central chemical laboratories, Egyptiah Electricity Authority.

4. T-S. Sidhu , ( 2006), S- Prakash and R-D . Agrawel "Hot Corrosion and Performance of Nickel - Based Coating, Current Science Vol . 9 , No.1 .

5. H. Singh, D. Puri and S. Prakash, "An Overview of Na2 SO4 and / or $\mathrm{V}_{2} \mathrm{O} 5$ Induced Hot Corrosion of $\mathrm{Fe}-$ and $\mathrm{Ni}$-Based Superalloys" . Rev . Adv . Mater. Sci. 16 (2007) 27-50 .

6. I . Andijani, (2004), and A-V . Mali, "Sulfur and Vanadinm Induced Hot Corrosion of Boiler Tubes ", Conference, King Sand University, Riyadh , on 11 to 15 Dec.

7. C.S. Giggins and F. S. Pettit, (1979) Hot Corrosion Degradation of Metals and Alloys: A vnified theory, Pratt and Whitney Report, FR-11545.

8. M.M. Barbooti, (2001)"Corrosion Inhibition-Magnesium compounds Additives to Heavy Fuel Oil",Chem. Arab,Beirut,10-14 January.

9. S. S. Dreymann and R. T. Henk, ( 1981) "Simplified System for Processing and Treating Ash-Forming Fuels", General Electric company Report GER-3132.

10.K. F. Al-Sultani, (2003)" A Pilot System for Evaluation of Hot Ash Corrosion Inhibition in Power Generation Boilers," Ph.D thesis, The Technology University. 
11.I. L. Rozenfeld, (1981) "Corrosion Inhibitor ",McGraw-Hill,New York.

12.R.A. Newby and R. I. Bannister, (1998) " A Direct Coal-Fired Combustion Turbine Power System Based on Slagging Gasification with in-sitn cas Cleasing", Trans ASME, 120, 450.

13.Child, H. G.,( 1985) "The Effect of Composition of Gas Turbine Alloys on Resistance of Scalling and Vanadium Pentoxide", J. I. S. I.. 